\title{
Carbonic anhydrase influences asymmetric sodium and acetate transport across omasum of sheep
}

\author{
Imtiaz Rabbani ${ }^{1}$, Habib Rehman ${ }^{1}$, Holger Martens ${ }^{2}$, Khalid Abdul Majeed ${ }^{1}$, \\ Muhammad Shahbaz Yousaf ${ }^{1}$, and Zia Ur Rehman ${ }^{3, *}$
}

\author{
* Corresponding Author: Zia Ur Rehman \\ Tel: +92-333-7474408, Fax: +92-62-9250235 \\ E-mail: zia.urrehman@iub.edu.pk \\ 'Department of Physiology, University of \\ Veterinary and Animal Sciences, Lahore \\ 54000, Pakistan \\ 2 Institute of Veterinary Physiology, Free \\ University of Berlin, Berlin 14163, Germany \\ ${ }^{3}$ Department of Physiology, University College \\ of Veterinary and Animal Sciences, The \\ Islamia University of Bahawalpur, 63100, \\ Pakistan \\ ORCID \\ Imtiaz Rabbani \\ https://orcid.org/0000-0003-3168-2684 \\ Habib Rehman \\ https://orcid.org/0000-0002-8485-7962 \\ Holger Martens \\ https://orcid.org/0000-0001-8062-8073 \\ Khalid Abdul Majeed \\ https://orcid.org/0000-0002-4929-4033 \\ Muhammad Shahbaz Yousaf \\ https://orcid.org/0000-0002-1106-6289 \\ Zia Ur Rehman \\ https://orcid.org/0000-0003-1452-3745
}

Submitted Mar 16, 2020; Revised May 13, 2020 ; Accepted Jun 5, 2020
Objective: Omasum is an important site for the absorption of short chain fatty acids. The major route for the transport of acetate is via sodium hydrogen exchanger (NHE). However, a discrepancy in the symmetry of sodium and acetate transport has been previously reported, the mechanism of which is unclear. In this study, we investigated the possible role of carbonic anhydrase (CA) for this asymmetry.

Methods: Omasal tissues were isolated from healthy sheep $(\mathrm{N}=3)$ and divided into four groups; $\mathrm{pH} 7.4$ and 6.4 alone and in combination with Ethoxzolamide. Electrophysiological measurements were made using Ussing chamber and the electrical measurements were made using computer controlled voltage clamp apparatus. Effect(s) of CA inhibitor on acetate and sodium transport flux rate of $\mathrm{Na}^{22}$ and ${ }^{14} \mathrm{C}$-acetate was measured in three different flux time periods. Data were presented as mean \pm standard deviation and level of significance was ascertained at $\mathrm{p} \leq 0.05$.

Results: Mucosal to serosal flux of $\mathrm{Na}\left(\mathrm{J}_{\mathrm{ms}} \mathrm{Na}\right)$ was greater than mucosal to serosal flux of acetate $\left(J_{\mathrm{ms}} \mathrm{Ac}\right)$ when the $\mathrm{pH}$ was decreased from 7.4 to 6.4. However, the addition of CA inhibitor almost completely abolished this discrepancy $\left(\mathrm{J}_{\mathrm{ms}} \mathrm{Na} \approx \mathrm{J}_{\mathrm{ms}} \mathrm{Ac}\right)$.

Conclusion: The results of the present study suggest that the additional protons required to drive the NHE were provided by the CA enzyme in the isolated omasal epithelium. The findings of this study also suggest that the functions of CA may be exploited for better absorption in omasum.

Keywords: Flux Measurements; Ovine; Short Circuit Current; Ussing Chamber

\section{INTRODUCTION}

Short chain fatty acids (SCFAs) namely acetate, propionate and butyrate are fundamental in providing energy to the ruminants and are products of microbial fermentation of the ingesta under anaerobic milieu. Rumen provides a complex environment for SCFAs production and is the major compartment where the absorption takes place [1]. The transport of SCFAs across ruminal epithelium has been extensively studied in sheep [2], swine and human colon [3]. Mostly, the transport is through carrier-mediated mechanisms that have been shown to occur through apical as well as basolateral membranes $[4,5]$. SCFAs transport is closely linked to sodium transport through sodium/hydrogen exchanger (NHE) in large intestine of guinea pigs, sheep, ponies and pigs [6,7].

Significant amount of microbial activity also exists in omasum and consequently SCFAs production and absorption takes place in omasum [8]. There is also an outflow of SCFAs from rumen into omasum depending on dry matter intake and consequent absorption in omasum [9]. The carrier-mediated transport of SCFAs in exchange for bicarbonate ions as occurs in rumen [4], is not possible in omasum because omasal epithelia have 
predominately absorptive bicarbonate function [1]. Transport mechanisms analogous to that of large intestine have been documented, where SCFAs namely acetate and sodium transport occurs via NHE in omasal epithelia of sheep, that is shown to be mutual but asymmetrical [10]. However, the cause of asymmetry in mutual transport of acetate and $\mathrm{Na}$ in epithelial transport in omasum remains unclear.

Several molecules have been identified as regulators of different isoforms of NHE, including but not limited to protein kinase A \& C [11], insulin [12], tenapanor hydrochloride [13]. In the current study, we have assumed that omasal intraepithelial carbonic anhydrase enzyme (CA) is contributing to asymmetry. The CA in present in many cells both intracellularly and on the surface. It is mainly involved in the reversible conversion of carbon dioxide and water to bicarbonate and protons also maintains acid-base balance [14]. Using acetate as the principal SCFA, mutual asymmetrical interaction between acetate and sodium transport via NHE was described previously [10], and the CA was inhibited to elucidate it as a factor responsible for asymmetry. This study specifically focuses on the possible role of CA in providing additional $\mathrm{H}^{+}$to the NHE and thus causing the asymmetry in the isolated omasal epithelium of sheep.

\section{MATERIALS AND METHODS}

\section{Animals}

Sheep (Ovis aries) $(\mathrm{N}=3)$ of almost alike age and weight from both sexes were selected. The animals were given hay ad libitum 2 weeks prior to experiment and had free access to water and a lick stone.

\section{Tissue collections and preparation}

Omasal samples were isolated from sheep $(\mathrm{N}=3)$ as previously described by Ali et al $[10,15]$. Briefly, sheep were killed after stunning at slaughterhouse of Free University of Berlin (FUB), Germany and the fore-stomachs were removed from abdomen within 3 to 4 minutes. Omasum was identified and separated from reticulorumen and abomasum, and was opened by a longitudinal cut down the omasal canal. The inner part was everted and washed with warm phosphate buffer saline (PBS). Eight to ten slices, each of approximately 250 to $300 \mathrm{~cm}^{2}$ surface area were sectioned from omasal wall. The mucosal surfaces were stripped from these slices with caution and transported to laboratory in Institute of Veterinary Physiology, FUB, within 25 minutes in warm $\left(38^{\circ} \mathrm{C}\right)$ and continuously gassed (95\% oxygen, $5 \%$ carbon dioxide) PBS. The protocols followed for animal housing and slaughtering adhered to guidelines of FUB, Germany (Ethical approval permit \# T0064/99).

\section{Experimental groups}

Experimental conditions were followed as described previously by Ali et al [10] with slight modifications. Selected omasal tissues were randomly divided into four different groups as pH 7.4 (Control) and pH 6.4 alone and in combination with Ethoxzolamide (Sigma, Taufkirchen, Germany).

\section{Electrical measurements}

A $3 \times 3 \mathrm{~cm}$ piece of omasal epithelium was used for mounting in Ussing chamber. A control buffer of $\mathrm{pH} 7.4$ was prepared with bicarbonate ions and SCFA concentration of $40 \mathrm{mmol} /$ litre. Control buffer was made as described previously by Rabbani et al [16] with slight modification. Briefly the control buffer constituted of (in milli-moles/litre): $\mathrm{NaCl}(20)$, $\mathrm{MgCl}_{2}(1), \mathrm{CaCl}_{2}(1), \mathrm{NaHCO}_{3}(25), \mathrm{K}_{2} \mathrm{HPO}_{4}(2), \mathrm{KH}_{2} \mathrm{PO}_{4}$ (1), Na-acetate (24), Na-propionate (12), Na-butyrate (4), Na-gluconate (20), and Glucose (10). The tissues were bathed with $16 \mathrm{~mL}$ of control buffer on each side of chamber at $38^{\circ} \mathrm{C}$. All the chambers were continuously gassed with $95 \% \mathrm{O}_{2}$ and $5 \% \mathrm{CO}_{2}$. At least 20 minutes were given for the electrophysiological measurements to stabilize. Following equilibration period, omasal tissues were considered viable and included in this study based on conductance $\left(\mathrm{G}_{\mathrm{t}}\right)<8.0 \mathrm{Ms} / \mathrm{cm}^{2}$ and short-circuit current $\left(\mathrm{I}_{\mathrm{sc}}\right)>1.0 \mu \mathrm{A} / \mathrm{cm}^{2}$ as described by Martens and Gabel [17].

\section{Flux measurements}

Unidirectional flux measurements were made as described previously by Ali et al [10]. Luminal side $\mathrm{pH}$ was adjusted to 6.4 or 7.4 using $1 \mathrm{mM} / \mathrm{L}$ hydrochloric acid or Tris-hydroxymethyl-aminomethan in respective groups with serosal $\mathrm{pH}$ of 7.4 in all chambers irrespective of groups. Omasal tissues were again stabilized under the new experimental conditions for about 25 minutes. Afterwards, $0.1 \mathrm{mM}$ ethoxzolamide was added on both sides of chamber to see effect of CA inhibitor on acetate and sodium transport Flux rate of $\mathrm{Na}^{22}$ and ${ }^{14} \mathrm{C}$-acetate was measured in three different flux time periods, each of 30 minutes.

For detection of fluxes of $\mathrm{Na}$ and acetate from mucosa to serosa $\left(J_{\mathrm{ms}}\right)$ and serosa to mucosa $\left(\mathrm{J}_{\mathrm{sm}}\right), 70-\mathrm{kBq}{ }^{22} \mathrm{Na}$ and 60 $\mathrm{kBq}{ }^{14} \mathrm{C}$-acetate radioactively labelled were used, respectively. After equilibration of tissues, ${ }^{14} \mathrm{C}$-acetate and ${ }^{22} \mathrm{Na}$ was added to the radioactively labelled side. A $100 \mu \mathrm{L}$ sample was taken from radioactively labelled side after 15 minutes (H1) and then at the end of the protocol (H2). Within 30 minutes between these samples, $1 \mathrm{~mL}$ samples were taken from the opposite side of radioactively labelled tissue. The volumes taken were replaced by control physiological buffer in each case with adjusted $\mathrm{pH}$. The samples collected from both the radioactively labelled side and opposite side were made in a $5 \mathrm{~mL}$ scintillator solution (Zinsser Analytic, Frankfurt, Germany). The solution was properly shaken for measuring the isotopes radioactivity using a $\beta$-counter Liquid Scintillation 
analyzer (Perkin Elmer, Überlingen, Germany). The electrical measurements were made using computer controlled voltage clamp apparatus (Micro clamp, Datentechnik, Aachen, Germany). The resistance of fluid in bridges for sensing Transepithelial potential difference $\left(\mathrm{T}_{\mathrm{PD}}\right)$ was measured before mounting of tissue and correction applied by computer controlled clamp apparatus. Tissues were kept in short-circuit condition throughout the experiment with the application of bipolar pulse of $100 \mu \mathrm{A}$ for 0.2 seconds duration. The change in $\mathrm{T}_{\mathrm{PD}}, \mathrm{I}_{\mathrm{sc}}$, and $\mathrm{G}_{\mathrm{t}}$ was calculated after every 10 seconds. The data was stored in voltage clamp apparatus computer software for further analysis. The model is depicted in Figure 1.

\section{Statistics}

The data was analyzed using Sigmaplot (Systat software Inc., San Jose, CA, USA, Version 11.0). One way analysis of variance with Tukey's test was used to compare the data. Data was presented as mean \pm standard deviation. Level of significance at $\mathrm{p} \leq 0.05$ was considered significant.

\section{RESULTS}

A decrease in $\mathrm{pH}$ of luminal side caused an increase in $\mathrm{J}_{\mathrm{ms}}$ of acetate and sodium. At pH 7.4, the sodium $\mathrm{J}_{\mathrm{ms}}$ was $7.23 \pm 0.84$. A decrease in $\mathrm{pH}$ to 6.4 significantly increased the $\mathrm{J}_{\mathrm{ms}}$ of sodium to $10.60 \pm 0.91(\mathrm{p}<0.05)$. Similar trend of increased was noticed with acetate having $\mathrm{J}_{\mathrm{ms}} 2.76 \pm 0.20$ at $\mathrm{pH} 7.4$ to $3.79 \pm$ 0.34 . The increase of the acetate was not statistically different. An asymmetrical increase was observed in sodium and acetate transport. The increment of $\mathrm{J}_{\mathrm{ms}}$ sodium was greater than $\mathrm{J}_{\mathrm{ms}}$ acetate when the $\mathrm{pH}$ was lowered from 7.4 to $6.4\left(\mathrm{~J}_{\mathrm{ms}} \mathrm{Na}\right.$
$>\mathrm{J}_{\mathrm{ms}}$ acetate). There was a net movement of sodium form mucosal to serosal side with $J_{\text {net }} 4.31 \pm 0.57$. The flux of acetate in $\mathrm{pH} 7.4$ did not show any net absorption or secretion $\left(J_{\mathrm{ms}} 2.76 \pm 0.20 \mathrm{vs} J_{\mathrm{sm}} 2.73 \pm 0.35\right)$ and the net transport of acetate was $\left(\mathrm{J}_{\text {net }}\right) 0.02 \pm 0.19$. This is shown in Tables 1 and 2 .

The inhibition of CA enzyme by ethoxzolamide at $\mathrm{pH} 7.4$ significantly decreased $\mathrm{J}_{\mathrm{ms}}$ of sodium from $7.23 \pm 0.84$ to $4.21 \pm$ $0.47(\mathrm{p}<0.05)$. The decrease was also noticed for acetate with $\mathrm{J}_{\mathrm{ms}} 2.76 \pm 0.20$ to $2.65 \pm 0.24$ ( $\mathrm{p}>0.05$ ). The lowering of $\mathrm{pH}$ from 7.4 to 6.4 with inhibition of CA through ethoxzolamide increased $\mathrm{J}_{\mathrm{ms}}$ acetate from $2.76 \pm 0.20$ to $3.53 \pm 0.28$ and $\mathrm{J}_{\mathrm{ms}}$ sodium from $7.23 \pm 0.84$ to $7.28 \pm 0.55$. The asymmetry in the increment of $J_{\mathrm{ms}} \mathrm{Na}$ and acetate $\left(\mathrm{J}_{\mathrm{ms}} \mathrm{Na}>\mathrm{J}_{\mathrm{ms}}\right.$ acetate) observed previously is almost absent in the presence of ethoxzolamide, due to CA inhibiton. The obtained data augment the hypothesis that the "missing" protons between uptake of acetate ( $\mathrm{pH}$ 6.4) and the stimulation of $\mathrm{J}_{\mathrm{ms}} \mathrm{Na}$ are produced by the activity of

Table 1. Effects of mucosal and serosal addition of Carbonic anhydrase inhibitor, ethoxzolamide $(0.1 \mathrm{mM})$, on unidirectional sodium flux rates of ovine omasum epithelium

\begin{tabular}{|c|c|c|c|c|}
\hline \multirow{2}{*}{ Items } & $\mathbf{J}_{m s}^{N a}$ & $\mathbf{J}_{s m}^{N a}$ & $\mathbf{J}_{n e t}^{\mathrm{Na}}$ & \multirow{2}{*}{$N / n$} \\
\hline & \multicolumn{3}{|c|}{$\mu \mathrm{eq} \cdot \mathrm{cm}^{-2} \cdot \mathrm{h}^{-1}$} & \\
\hline $\mathrm{pH} 7.4$ & $7.23 \pm 0.84^{a}$ & 2. $91 \pm 0.72^{a}$ & $3.70 \pm 0.45^{\mathrm{ab}}$ & $3 / 14$ \\
\hline $\mathrm{pH} 7.4$ with CAl & $4.21 \pm 0.47^{b}$ & $2.1 \pm 0.19^{a}$ & $2.25 \pm 0.26^{b}$ & $3 / 17$ \\
\hline $\mathrm{pH} 6.4$ & $10.60 \pm 0.91^{c}$ & $5.41 \pm 0.75^{b}$ & $4.49 \pm 0.71^{a}$ & $3 / 19$ \\
\hline $\mathrm{pH} 6.4$ with CAl & $7.28 \pm 0.55^{a}$ & $4.55 \pm 0.41^{b}$ & $2.73 \pm 0.25^{\mathrm{ab}}$ & $3 / 16$ \\
\hline
\end{tabular}

Data is represented as mean \pm standard error of the mean.

$\mathrm{N}$, number of animals; $n$, number of tissues; CAl, carbonic anhydrase inhibitor.

${ }^{\text {a-c }}$ Means with different superscripts within a column differ significantly $(p<0.05)$

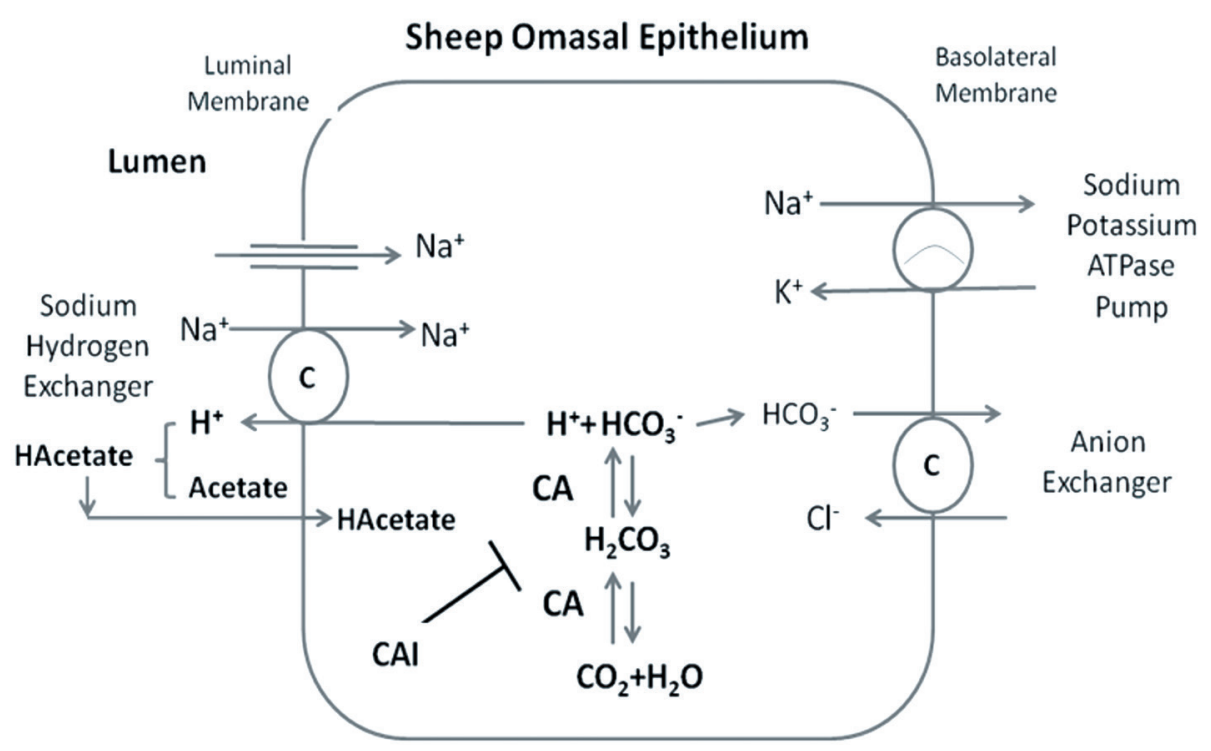

Figure 1. Inhibiton of carbonic anhydrase enzyme (CAI) through ethoxzolamide in sheep omasal epithelia and its link with sodium and acetate transport. $\mathrm{C}$ indicates carrier transport ers $\left(\mathrm{Na}^{+} / \mathrm{H}^{+}\right.$exchanger and $\mathrm{Cl}^{-} / \mathrm{HCO}_{3}{ }^{-}$exchanger). $\mathrm{CA}$ indicates carbonic anhydrase enzyme (Model adapted from $[18,19])$. 
Table 2. Effects of mucosal and serosal addition of Carbonic anhydrase inhibitor, ethoxzolamide $(0.1 \mathrm{mM})$, on unidirectional acetate flux rates of ovine omasum epithelium

\begin{tabular}{|c|c|c|c|c|}
\hline \multirow{2}{*}{ Items } & $\mathbf{J}_{m s}^{A c}$ & $\mathbf{J}_{s m}^{A c}$ & $\mathbf{J}_{n e t}^{A c}$ & \multirow{2}{*}{$N / n$} \\
\hline & \multicolumn{3}{|c|}{$\mu \mathrm{eq} \cdot \mathrm{cm}^{-2} \cdot \mathrm{hr}^{-1}$} & \\
\hline $\mathrm{pH} 7.4$ & $2.76 \pm 0.20^{\mathrm{ab}}$ & $2.73 \pm 0.3$ & $-0.23 \pm 0.28^{a}$ & $3 / 14$ \\
\hline $\mathrm{pH} 7.4$ with $\mathrm{CAl}$ & $2.65 \pm 0.24^{a}$ & $2.83 \pm 0.49$ & $-0.19 \pm 0.29^{a}$ & $3 / 17$ \\
\hline $\mathrm{pH} 6.4$ & $3.79 \pm 0.34^{b}$ & $2.66 \pm 0.27$ & $1.13 \pm 0.42^{b}$ & $3 / 18$ \\
\hline $\mathrm{pH} 6.4$ with $\mathrm{CAl}$ & $3.53 \pm 0.28^{\mathrm{ab}}$ & $3.43 \pm 0.24$ & $0.09 \pm 0.18^{a}$ & $3 / 16$ \\
\hline
\end{tabular}

Data is represented as mean \pm standard error of the mean.

$\mathrm{N}$, number of animals; $\mathrm{n}$, number of tissues; CAl, carbonic anhydrase inhibitor.

$a, b$ Means with different superscripts within a column differ significantly $(p<0.05)$

\section{CA (Figure 2).}

\section{DISCUSSION}

Considerable amounts of SCFAs are produced in the rumen and reticulum namely acetate, propionate and butyrate [20]. The role of omasum in this context has not been investigated much and fewer reports $[1,8,10]$ highlight the fermentative and absorptive capability of omasum in context of SCFAs. Furthermore, there is paucity in literature about the moonlighting role of CA in fermentation and absorption of SCFAs in omasum. In the current study, there is very little transport of acetate in omasal epithelia $\left(J_{\text {net }}=0.02 \pm 0.19\right)$ at $\mathrm{pH} 7.4$ as shown in Table 2 indicating absence of an active transport mechanism for acetate. Similar finding has been shown for butyrate at $\mathrm{pH} 7.38$ where the net flux was $0.1 \pm 0.3 \mu \mathrm{eq} / \mathrm{cm}^{2} / \mathrm{h}$ in distal colon of rats [21]. In isolated colon of pigs, there is an increase in net sodium absorption and bicarbonate accu-

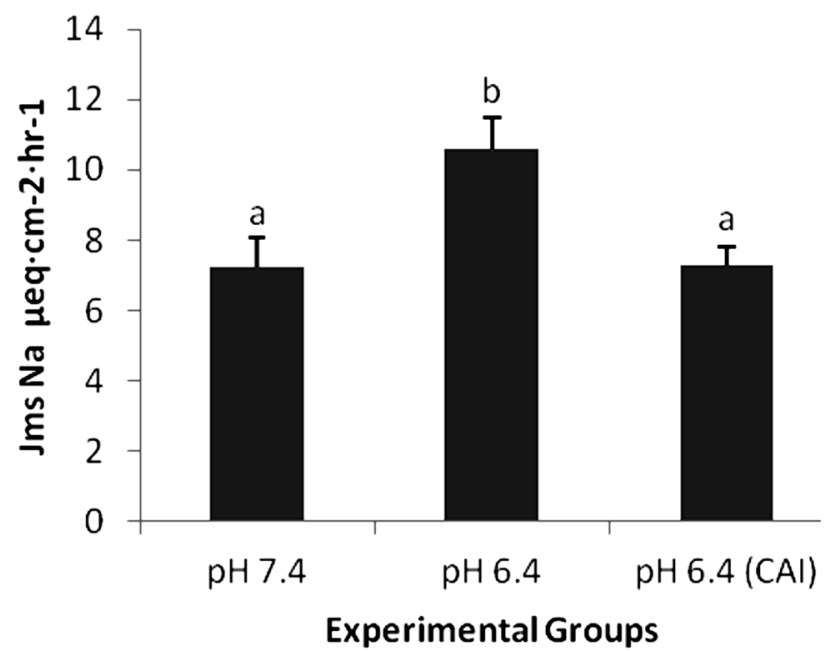

Figure 2. Effect of the addition of carbonic anhydarase inhibitor (CAI) on sodium flux $\left(\mathrm{J}_{\mathrm{ms}} \mathrm{Na} \mathrm{\mu eq} \cdot \mathrm{cm}^{-2} \cdot \mathrm{h}^{-1}\right)$. The addition of CAl on mucosal side significantly abolishes $(\mathrm{p}<0.05)$ the $\mathrm{pH}$ dependent asymmetry. mulation on the luminal side in presence of acetate signifying that acetate may provide an energy source for active sodium transport in colonic epithelium [22]. Similar carrier mechanisms of acetate bicarbonate exchange have been shown in rumen [23], which are unlikely in omasal epithelia because of their absorptive tendency for bicarbonate ions [1].

A decrease in $\mathrm{pH}$ to 6.4 from 7.4 considerably increased the $J_{m s}$ acetate to $3.79 \pm 0.34$ from $2.76 \pm 0.20$ and $J_{\text {net }} 1.13 \pm 0.42$ from $0.02 \pm 0.19$ (Table 2). There is an increase in protonated form of acetate by decrease in omasal luminal $\mathrm{pH}$, which is lipophilic and easy to pass through the membrane [10]. The decrease in $\mathrm{pH}$ from 7.4 to 6.4 of the mucosal side of omasal epithelia increased the $\mathrm{J}_{\mathrm{ms}}$ sodium and acetate fluxes mutually. Sodium hydrogen exchanger and its interaction with butyrate is studied in cultured ruminal epithelial cells of sheep where intra-epithelial acidification by butyrate is counter-regulated by NHE [24]. A compelling evidence also exists regarding presence of NHE on the luminal wall of the rumen and omasum, which is sensitive to amiloride (inhibitor of NHE) when applied on the mucosal side [17].

Reciprocated interaction has been shown between; propionate or butyrate and sodium transport in proximal colon of rabbits [25], butyrate and sodium transport in distal colon of rat [26], butyrate and sodium transport in gallbladder of guinea pig [27]. Asymmetry in transport fluxes in ovine omasum is reported (10) where $\mathrm{J}_{\mathrm{ms}}$ of sodium was greater than $\mathrm{J}_{\mathrm{ms}}$ acetate when $\mathrm{pH}$ was lowered from 7.4 to 6.4. This shared but unequal interaction between acetate and sodium transport via NHE is presumably because of the role of $\mathrm{CA}$. The CA uses intra-epithelial carbon dioxide and water to provides protons $\left(\mathrm{H}^{+}\right)$and bicarbonate $\left(\mathrm{HCO}_{3}^{-}\right)$ions, and $\mathrm{H}^{+}$is exchanged for sodium through NHE [18]. The inhibition of CA decreased the $\mathrm{J}_{\mathrm{ms}}$ sodium from $10.60 \pm 0.91$ ( $\mathrm{pH}$ 6.4) to $7.28 \pm 0.55$ (pH 6.4 with CA inhibition). This was only slightly increased compared to $\mathrm{J}_{\mathrm{ms}}$ sodium of $7.23 \pm 0.84$ at $\mathrm{pH}$ 7.4. In sheep omasal epithelium, the $\mathrm{H}^{+}$ion transported to mucosal side through NHE bind with acetate and the protonated SCFA (HSCFA) is formed [17]. HSCFA are lipid soluble and tend to equilibrate through a concentration gradient mechanism from omasal mucosa to intracellular epithelium [21]. The acetate flux $\mathrm{J}_{\mathrm{ms}}$ also decreased from $3.79 \pm 0.34$ (pH 6.4) to $3.53 \pm 0.28$ (pH 6.4 with CA inhibition). The asymmetry observed in the present study and by Ali et al [10] was removed through CA inhibition and statistically non-significant $\mathrm{J}_{\mathrm{ms}}$ at $\mathrm{pH} 7.4$ and $\mathrm{pH} 6.4$ with CA inhibition for acetate $(2.76 \pm 0.20$ and $3.53 \pm 0.28)$ and sodium (7.23 \pm 0.84 and $7.28 \pm 0.55)$ were observed.

\section{CONCLUSION}

It can be deduced that intra-epithelial CA enzyme is responsible for asymmetry in mutual transport of acetate and sodium. 
The asymmetry was successfully removed by inhibition of CA by ethoxzolamide. This appeared to be the first study exploring the role of CA in SCFAs transport in sheep abomasum. CA may be a potential target for exploitation to improve the absorption of SCFAs in omasum and contribute in better and cost effective production.

\section{CONFLICT OF INTEREST}

We certify that there is no conflict of interest with any financial organization regarding the material discussed in the manuscript.

\section{ACKNOWLEDGMENTS}

The author is a recipient of a scholarship from a German funding Agency (DAAD). Assistance in the lab work by Mr. Uwe Tietjen is highly appreciated and acknowledged.

\section{REFERENCES}

1. von Engelhardt W, Hauffe R. Functions of the omasum in small domestic ruminants. IV. Absorption and secretion of electrolytes. Zentralbl Veterinarmed A 1975;22:367-75. https://doi.org/10.1111/j.1439-0442.1975.tb01442.x

2. Kramer T, Michelberger T, Gürtler H, Gäbel G. Absorption of short-chain fatty acids across ruminal epithelium of sheep. J Comp Physiol B 1996;166:262-9. https://doi.org/10.1007/ BF00262870

3. Ritzhaupt A, Wood IS, Ellis A, Hosie KB, Shirazi-Beechey SP. Identification and characterization of a monocarboxylate transporter (MCT1) in pig and human colon: its potential to transport L-lactate as well as butyrate. J Physiol 1998;513: 719-32. https://doi.org/10.1111/j.1469-7793.1998.719ba.x

4. Gäbel G, Aschenbach JR, Müller F. Transfer of energy substrates across the ruminal epithelium: implications and limitations. Anim Health Res Rev 2002;3:15-30. https://doi.org/ 10.1079/AHRR200237

5. Tyagi S, Venugopalakrishnan J, Ramaswamy K, Dudeja PK. Mechanism of $\mathrm{n}$-butyrate uptake in the human proximal colonic basolateral membranes. Am J Physiol Gastrointest Liver Physiol 2002;282:G676-82. https://doi.org/10.1152/ ajpgi.00173.2000

6. von Engelhardt W, Burmester M, Hansen K, Becker G, Rechkemmer G. Effects of amiloride and ouabain on short-chain fatty acid transport in guinea-pig large intestine. J Physiol 1993;460:455-66. https://doi.org/10.1113/jphysiol.1993.sp 019481

7. von Engelhardt W, Burmester M, Hansen K, Becker G. Unidirectional fluxes of short-chain fatty acids across segments of the large intestine in pig, sheep and pony compared with guinea pig. J Comp Physiol B 1995;165:29-36. https://doi.
org/10.1007/BF00264683

8. Smith RH. Microbial activity in the omasum. Proc Nutr Soc 1984;43:63-8. https://doi.org/10.1079/PNS19840028

9. Tamminga S, van Vuuren AM. Formation and utilization of end products of lignocellulose degradation in ruminants. Anim Feed Sci Technol 1988;21:141-59. https://doi.org/10. 1016/0377-8401(88)90096-X

10.Ali O, Shen Z, Tietjen U, Martens H. Transport of acetate and sodium in sheep omasum: mutual, but asymmetric interactions. J Comp Physiol B 2006;176:477-87. https://doi. org/10.1007/s00360-006-0069-8

11.Boron WF, Boulpaep EL. Medical physiology: a cellular and molecular approaoch. 3rd ed. Philadelphia, PA, USA: Saunders/ Elsevier; 2017.

12. Klisic J, Hu MC, Nief V, et al. Insulin activates $\mathrm{Na}^{+} / \mathrm{H}^{+}$exchanger 3: biphasic response and glucocorticoid dependence. Am J Physiol Renal Physiol 2002;283:F532-9. https://doi.org/ 10.1152/ajprenal.00365.2001

13.Spencer AG, Labonte ED, Rosenbaum DP, et al. Intestinal inhibition of the $\mathrm{Na}^{+} / \mathrm{H}^{+}$exchanger 3 prevents cardiorenal damage in rats and inhibits $\mathrm{Na}^{+}$uptake in humans. Sci Transl Med 2014;6:227ra36. 10.1126/scitranslmed.3007790

14. Badger MR, Price GD. The role of carbonic anhydrase in photosynthesis. Annu Rev Plant Physiol Plant Mol Biol 1994;45:369-92. https://doi.org/10.1146/annurev.pp.45. 060194.002101

15. Martens H, Kudritzki J, Wolf K, Schweigel M. No evidence for active peptide transport in forestomach epithelia of sheep. J Anim Physiol Anim Nutr 2001;85:314-24. https://doi.org/ 10.1046/j.1439-0396.2001.00319.x

16. Rabbani I, Siegling-Vlitakis C, Noci B, Martens H. Evidence for $\mathrm{NHE}^{3}$-mediated $\mathrm{Na}$ transport in sheep and bovine forestomach. Am J Physiol Regul Integr Comp Physiol 2011;301: R313-9. https://doi.org/10.1152/ajpregu.00580.2010

17. Martens H, Gabel G. Transport of $\mathrm{Na}$ and $\mathrm{Cl}$ across the epithelium of ruminant forestomachs: rumen and omasum. A review. Comp Biochem Physiol A Physiol 1998;90:569-75. https://doi.org/10.1016/0300-9629(88)90669-X

18. Çaushi D. Transport of $\mathrm{HCO}_{3}$ in sheep omasum [dissertation]. Berlin, Germany: Freie Universität Berlin; 2015.

19. Gäbel G, Sehested J. SCFA transport in the forestomach of ruminants. Comp Biochem Physiol A Physiol 1997;118:36774. https://doi.org/10.1016/S0300-9629(96)00321-0

20. Allen MS. Relationship between fermentation acid production in the rumen and the requirement for physically effective fiber. J Dairy Sci 1997;80:1447-62. https://doi.org/10.3168/ jds.S0022-0302(97)76074-0

21. Charney AN, Micic L, Egnor RW. Nonionic diffusion of shortchain fatty acids across rat colon. Am J Physiol Gastrointest Liver Physiol 1998;274:G518-24. https://doi.org/10.1152/ ajpgi.1998.274.3.G518

22. Argenzio RA, Whipp SC. Inter-relationship of sodium, chloride, 
bicarbonate and acetate transport by the colon of the pig. J Physiol 1979;295:365-81. https://doi.org/10.1113/jphysiol. 1979.sp012974

23. Gäbel P, Bestmann M, Martens H. Influences of diet, shortchain fatty acids, lactate and chloride on bicarbonate movement across the reticulo-rumen wall of sheep. J Vet Med A 1991;38:523-9. https://doi.org/10.1111/j.1439-0442.1991.tb 01043.x

24. Müller F, Aschenbach JR, Gäbel G. Role of $\mathrm{Na}^{+} / \mathrm{H}^{+}$exchange and $\mathrm{HCO}_{3}$ transport in $\mathrm{pH}_{\mathrm{i}}$ recovery from intracellular acid load in cultured epithelial cells of sheep rumen. J Comp Physiol B 2000;170:337-43. https://doi.org/10.1007/s003600000107
25. Butzner JD, Meddings JB, Dalal V. Inhibition of short-chain fatty acid absorption and $\mathrm{Na}^{+}$absorption during acute colitis in the rabbit. Gastroenterology 1994;106:1190-8. https://doi. org/10.1016/0016-5085(94)90009-4

26. Binder HJ, Mehta P. Characterization of butyrate-dependent electroneutral $\mathrm{Na}-\mathrm{Cl}$ absorption in the rat distal colon. Pflugers Arch 1990;417:365-9. https://doi.org/10.1007/BF00370654

27.Petersen KU, Wood JR, Schulze G, Heintze K. Stimulation of gallbladder fluid and electrolyte absorption by butyrate. J Membr Biol 1981;62:183-93. https://doi.org/10.1007/BF019 98164 